\title{
Influence of Product Quality, Price and Supporting Infrasturcture to Perceived Value and Interest in Buying of Electric Motorcycle
}

\author{
Edwin Sholeh Rahmanullah, ${ }^{1}$, Siti Nurjanah ${ }^{2}$ \\ ${ }^{1}$ Kalbis Institite, Magister Management, Faculty of Business \\ ${ }^{2}$ Kalbis Institite, Magister Management, Faculty of Business
}

\begin{abstract}
Energy consumption in Indonesia always increase every year. Transportation sector is the highest energy increase among other sector, totally transportation sector consump 35\% energy. Motorcycle, especially automatic type is dominate population of vehicle. This research want to know the influence of several factor to the interest of buying electric motorcycle. From research result we can conclude that product quality, price and supporting infrastructure have positive influence to both of perceived value and interest in buying of electric motorcycle. Direct relation between those three factors to interest in buying electric motorcycle is higher than indirect relation when through perceived value. For example comparing direct effect of product quality is 0,147 to indirect effect is 0,04674 . Other data from this research, $91 \%$ of the respondents can accept if the speed of an electric motorcycle under $100 \mathrm{~km} /$ hour. In general most respondents or $97.5 \%$ of respondents require mileage $>50 \mathrm{~km}$ for one time battery charging. Total $85 \%$ of respondents can accept charging time over 1 hour. Total $95 \%$ of respondents can accept a price range between $10-30$ million rupiah for each unit of electric motorcycle. For infrastructure, respondents who want a feature of charging directly (charging) and replacement batteries (swap) on electric motorcycle, desired by more than $86 \%$ of respondents.
\end{abstract}

Keywords : electric vehicle; motorcycle; buying interest; perceived value; product quality; price; supporting infratructure.

\section{Introduction}

Energy consumption in Indonesia always increase every year. Transportation sector is the highest energy increase among other sector, with $6,46 \%$ average. Totally transportation sector consump $35 \%$ energy, second highest after industrial sector. This is because of vehicle population increase $13,7 \%$ every year.

The bad news is to fulfill this needs Indonesia still depend on gasoline and other non renewable energy. It is very risky for Indonesia's future energy sutainability. Refer to BPS data at 2014, total vehicle population in Indonesia is 104.118.969 vehicles. And the bigest population is Jakarta, with 14.734.601 vehicles. Form this population $75 \%$ are motorcycle. Matic type motorcycle is dominate almost $72,9 \%$ market share of motorcycle sales in the year of 2016.

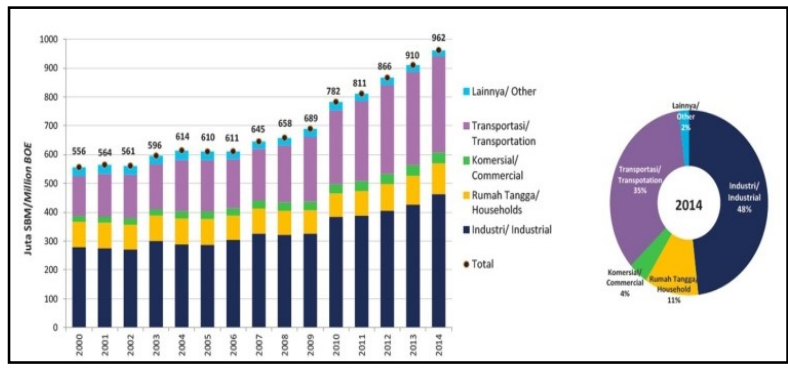

Fig 1.1. National Energy Consumption at Each Sector (Resource : KESDM (2015) Strategic Planning,Ministry of Energy and Mineral Resource 2015-2019, Jakarta.[1])

There is alternative vehicle to overcome from gasoline dependency, we can use electric vehicle. In motorcycle sector there is also electric motorcyle or electric scooter. China is dominate electric motorcycle sales around the world. 


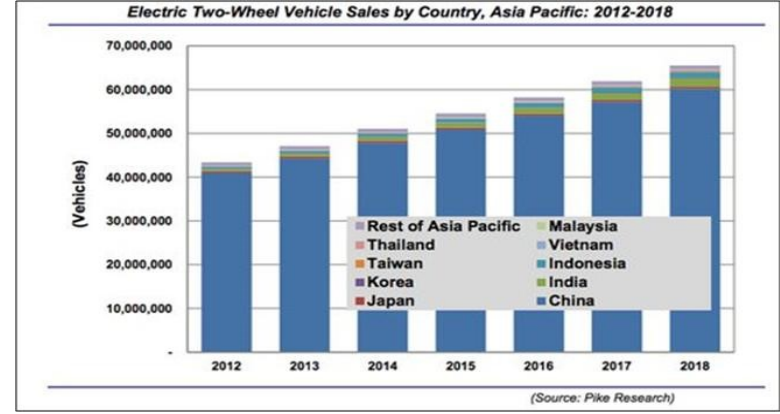

Fig 1.2. Electric 2 wheel Vehicle Sales by Country in Asia (Resource : Pike Research [2])

In Indonesia electric motorcycle sales is at small amount. Refer to National Energy Council target, there is 2.200 units of electric vehicle and 8.000.000 units of electric motorcycle in Indonesia at 2025.

To fulfill this target is not only to develop product, industry and other infrastructure, but need to have a strategy to sale electric motorcycle at Indonesian market. We need to understand what market need and what is market perception to electric motorcycle.

\begin{tabular}{|c|c|c|c|c|}
\hline \multicolumn{4}{|c|}{ E.Motorecyclo and E.Scootoro Oofintions by Rogion } & \\
\hline Region & E-Motorcycle & E.Scooter & & 0 \\
\hline North Amencica & $\begin{array}{r}\text { Top spoed }>30 \text { moph and Motor } \\
\text { size }>3 \mathrm{KW} \text { (Peak) }\end{array}$ & $\begin{array}{l}\text { Top speed }>20 \mathrm{mph} \text { and no } \\
\text { more than } 30 \mathrm{mph}\end{array}$ & & \\
\hline Latn America & Top speed $>45 \mathrm{kph}$ & $\begin{array}{l}\text { Top speed }>25 \mathrm{kgh} \text { and no } \\
\text { mocet than } 45 \mathrm{kgh}\end{array}$ & & \\
\hline Westem Europe & Top speed $>45 \mathrm{kph}$ & $\begin{array}{l}\text { Top speed } 325 \mathrm{kph} \text { and no } \\
\text { more than } 45 \mathrm{khh}\end{array}$ & & \\
\hline Eastem Europe & Top speed > $45 \mathrm{kph}$ & $\begin{array}{l}\text { Top speed }>25 \mathrm{kph} \text { and no } \\
\text { more than } 45 \mathrm{kghh}\end{array}$ & & \\
\hline Asia Pracic & Top speed >50 kph & $\begin{array}{r}\text { Top speed } 25 \mathrm{kph} \text { and no } \\
\text { more than } 50 \mathrm{kph} \text {, and vehide } \\
\text { weight over } 40 \mathrm{~kg}\end{array}$ & ZEROS & Honda EV \\
\hline Mudle East:Atrica & Top speed $>50 \mathrm{kph}$ & 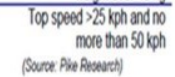 & $\begin{array}{c}\text { E- } \\
\text { Motorcycle }\end{array}$ & $\begin{array}{c}\text { Neo } \\
\text { E-Scooter }\end{array}$ \\
\hline
\end{tabular}

Fig 1.3. Two type of 2 wheel electric vehicle: EMotorcycle dan E-Scooter

This research want to know the influence of several factor to the interest of buying electric motorcycle. To build interest of buying there is perceived value factor in buyer perception. In the term of electric motorcycle there is 3 dominant factor, refer to previous research at other country, product quality, pice and supporting infrastructure.

\section{Research methodology}

\subsection{Interest in Buying}

According to Kinnear and Taylor [3], buying interest is the stage of respondent's tendency to act before the buying decision is actually implemented.

According to Ferdinand [4], buying interest can be identified through the following indicators:

1. Transactional interest, namely the tendency of someone to buy the product.
2. Referential interest, the tendency of a person to reference the product to others.

3. Preferential interest, this interest is describes the behavior of someone who has a primary preference for the product. This preference can only be changed if something happens with its preference product.

4. Explorative interest, this interest describes the behavior of a person who is always looking for information about the product he is interested in and seeking information to support the positive traits of the product.

\subsection{Perceived Value}

According to Kotler [5] "customer perceived value is the difference between the perspective of customer's evaluation of all benefits and all the costs of an offering and the perceived alternatives".

Sanchez, et al [6], explains that there is a benefit component and sacrifice component in assessing perceived value. Benefit components consist of:

1. Economic benefit: relates to what customers get from the product.

2. Emotional benefit: shows the affective benefits that customers get from the product.

3. Social benefits: show positive recognition of the brand that will recommend to relatives / friends.

4. Relationship benefits: the state where the expectations of customers in accordance with the needs of customers.

For sacrifice component consists of:

1. Price sacrifice: related to monetary costs as perceived by customers.

2. Time sacrifice: relates to the customer in spending time looking for, buying or consuming products / services.

3. Effort sacrifice: related to the energy customers spend to find and buy products / services.

4. Risk: the probability of negative consequences of purchasing products / services.

5. Inconvenience: related to the customer having a bad experience of purchasing products / services.

\subsection{Product Quality}

In electric motorcycle there is 3 important items related to product quality : vehicle speed, driving range and charging time. As we know there is a worries about vehicle speed of electric motorcycle comparing to gasoline motorcyle, so we need to know this factor influencies for cutomer. 
As limitation of battery capacity as energy storage at electric motorcycle, it will take effect to vehicle driving range. Comparing to gasoline motorcycle, electric motorcycle have less driving range. As a consequence of the current technological limitations, only average electric vehicles have a distance of about $160 \mathrm{~km}$ for a one-time filling. For electric motorcycle even far below that number. The ability of electric vehicle mileage at this time has not been able to meet the desires of customers. For example, nearly $60 \%$ of respondents in a survey that requires a minimum mileage of $160 \mathrm{~km}$. (Deloitte, [7])

For gasoline motorcycle we only need several minute to refueling gasoline. But, for electric vehicle we need several hours to recharge the battery. Therefore, refueling time becomes a more important factor than vehicle mileage. (Segal, [8]). So, we need to know cuctomer perception on these three factors.

\subsection{Price}

Electric vehicle are still more expensive than gasoline vehicle. Price is important factor influencing customer on interest in buying of electric motorcycle.

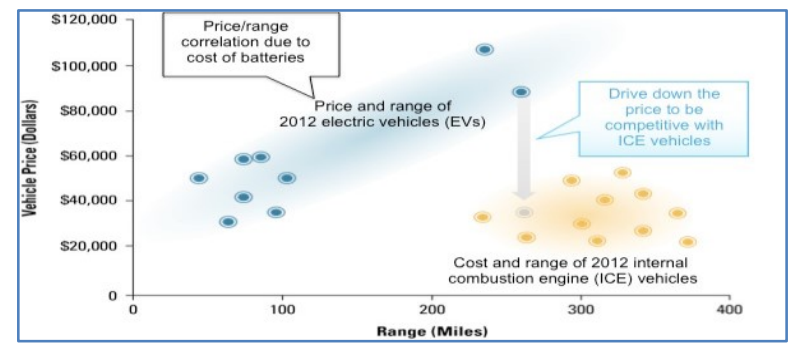

Fig2.1. Price Comparation Electric Vehicle and Internal

Combution Engine (ICE)(Resource: Ping Liu, et al

(2015) Long-range, Low-cost Electric Vehicles Enabled by Robust Energy Storage, MRS Energy \& Sustainability [9])

According to Greene [10] and Mau et al. [11] purchase price is the most important factor in determining purchasing decisions, as all other factors depend on price.

\subsection{Supporting Infrastructure}

Based on the American Public Works Association, infrastructure is defined as the physical facilities developed or required by public agencies for government functions in water supply, electric power, waste disposal, transportation and similar services to Facilitate economic and social objectives.

For electric motorcycle the supporting infratructure is charging infrastructure. There is also another alternative of infrastructure, by swapping the battery. This battery swap station is alternative infrastructure, this method is quicker than charging station.
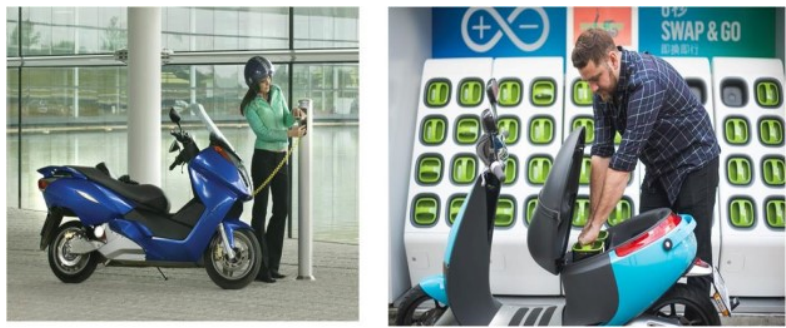

Fig 2.2. Illustration of Charging Station (left) dan Battery Swap Station (right)

\subsection{Correlation Between Each Variable Base on Previous Research}

Rachmad Dodi Triawan [12] from the Department of Management, Faculty of Economics, State University of Surabaya in a journal entitled: "The Influence of Brand Image and Perception Value Against Motorcycle Buying Purpose Brand Honda Type PCX 150 (Study on Cafe Visitor at Tunjungan Plaza Surabaya), which Published in Journal of Management Sciences Volume 05 Number 01 - Department of Management Faculty of Economics, State University of Surabaya, said that there is a positive relationship between perceived value (purchase perceived value) and purchase intention (buying interest). Where the higher the perception of the value of motorcycle products will increase purchasing intentions against the motorcycle.

Ning Wang and Yafei Liu [13] from the School of Automotive Studies, Tongji University, Shanghai, in his journal entitled "Key factors influencing customers' willingness to purchase electric vehicles in China", citing the results of his research that there is a positive relationship between the readiness of supporting infrastructure Electric vehicle (electric vehicle) with customer buying interest in China.

In the Thesis entitled "Analysis of Factors Influencing Interest in Buying New Yamaha Motorcycles in Semarang City", Agus Sukasman Hidayat [14], from Master Program Management of Postgraduate Program of Diponegoro University of Semarang, said that there is a positive influence on competitive prices with an interest in purchasing a motorcycle.In addition, this study also mentions that there is a positive influence between the quality of motorcycle products with buying interest.

Surya Danu Kusmono [15] from Master Program of Postgraduate Program Management of Widya Mandala Catholic University Surabaya, on his thesis entitled "The Influence of Marketing Mix Against Perceived Value and Purchasing Decision of ACR Brand Energy Saving Lamp Products in Surabaya", stated that there is influence between product, price, promotion and place against perceived value.

William Sierzchula, Sjoerd Bakker, et.al [16] from Delft University of Technology, Faculty of Technology, Policy, and Management, The Netherlands, on his research paper, entitled "The influence of financial incentives and other socio-economic Factors on electric 
vehicle adoption ", states that charging infrastucture has a positive influence on customer adoption of electric vehicles (electric vehicle).

\subsection{Research Conceptual Model \& Variables}

Refer to literature study this research conceptual model refer to Fig 3.1.

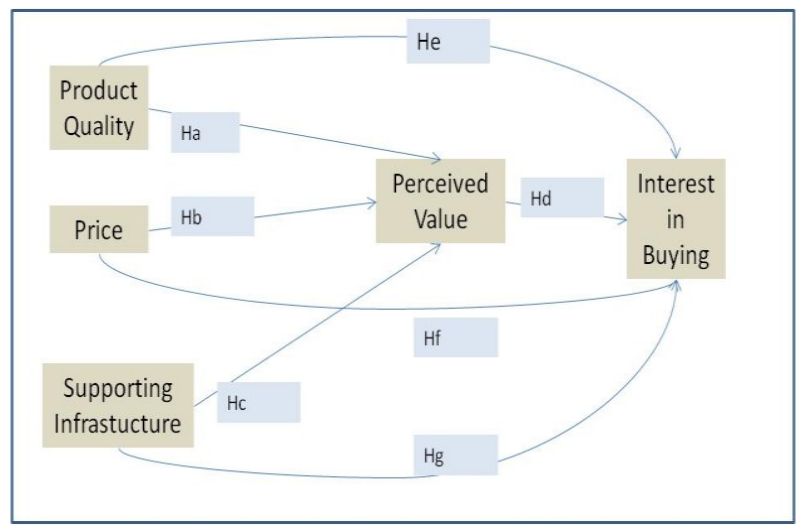

Fig 2.3 Research Conceptual Model

From this conceptual model, there is 4 independent variables : Product Quality, Price, Infrastructure and Perceived Value. Interest in Buying is dependent variable.

This research has 7 hypothesis as follows:

1. Ha: There is a positive influence between electric motor technology with perceived value

2. $\mathrm{Hb}$ : There is a positive influence between price and perceived value

3. Hc: There is a positive influence between supporting infrastructure and perceived value

4. Hd: There is a positive influence between perceived value and buying interest

5. He: There is a positive influence between electric motor technology with buying interest

6. Hf: There is a positive influence between price and buying interest

7. $\mathrm{Hg}$ : There is a positive influence between supporting infrastructure and buying interest

\subsection{Unit Analysis, Population \& Samples}

In this research is determined his unit of analysis is a motorcycle rider in Jakarta.The population of motorcycle users of automatic type in Jakarta in this study can not be known with certainty.

The population of this research is all owners and users of motorcycle type automatic in Jakarta. Because the amount is not known for certain then used sampling technique for infinite population as follows :

Information:
- $\quad \mathrm{N}=$ number of samples

- $\quad \mathrm{Z}=$ confidence level

- Moe $=$ Margin of Error

With a confidence level of $95 \%$ or $Z=1.96$ and a maximal sample error rate that can still be tolerated or moe by $10 \%$ then the sample size can be determined as follows:

$$
\begin{array}{r}
\mathrm{n}=\frac{1,96^{2}}{4(0,1)^{2}} \\
\mathrm{n}=\frac{3,8416}{0,04} \\
\mathrm{n}=96,04
\end{array}
$$

Based on the above calculation results obtained a good number of samples of the population at least 96.04 people. But to facilitate the calculation and because of the elements of rounding, so that in this study targeted the sample used at least amounted to 100 respondents.

Sampling in this research will use non-probability sampling approach that is sampling technique that does not give equal opportunity or opportunity for every element or member of population to be chosen as sample. The sampling used is purposive sampling technique. In this technique, the writer approached the prospective respondents. Then the authors asked whether the prospective respondent is a motorcycle user type matic and meet the specified sample requirements, in accordance with specific objectives in this study. If true candidate respondents qualify then the author asked the person's permission to become respondents.

\subsection{Pre Test \& Main Test}

\section{Validity \& Reliability Test}

This research tested the validity using product moment correlation, the formula is:

$$
\mathrm{r}_{\mathrm{XY}}=\frac{n \sum X_{i} Y_{i}-\left(\sum X_{i}\right)\left(\sum Y_{i}\right)}{\sqrt{\left[n \sum X_{i}^{2}-\left(\sum X_{i}\right)^{2}\right]}\left[n \sum Y_{i}^{2}-\left(\sum Y_{i}\right)^{2}\right]}
$$

Where :

$$
\begin{aligned}
& \mathrm{r}=\text { Product moment correlation } \\
& \mathrm{x}=\text { Score of each question } \\
& \mathrm{N}=\text { total sample } \\
& \mathrm{y}=\text { total score }
\end{aligned}
$$

Furthermore, by statistical methods, the correlation value obtained must be tested first by stating whether the value is significant or not. The correlation test is done by comparing $r$ obtained with product moment $\mathrm{r}$ in table, seen from $\mathrm{n}=$ number of respondents 
with $\alpha=5 \%$ or at $95 \%$ confidence level, then $\mathrm{r}$ table $(0,05,30)=0,361$.

\section{Basic decision making:}

- If $r$ count $>r$ table, then the questionnaire question is valid.

- If $r$ arithmetic $<r$ table, then the questionnaire question is invalid.

Reliability test is an instrument used to indicate the extent to which a measurement result is relatively consistent if the measuring device is used repeatedly. Of the many techniques to measure reliability, the authors used the Cronbach Alpha technique, the formula is as follows:

$$
\mathrm{r}_{\text {apha }}=\left[\frac{k}{(k-1)}\right]\left[1-\frac{\sum s_{b}^{2}}{\sum s_{t}^{2}}\right]
$$

Information :

$$
\mathrm{r} \text { alpha }=\text { instrument reliability }
$$

$\mathrm{K} \quad=$ Number of questions

$$
\begin{aligned}
& \sum_{s_{i}^{2}}=\text { Number of grain variants } \\
& \sum_{s_{s}^{2}} s_{t}^{2}=\text { Total Variant }
\end{aligned}
$$

\section{Classic Assumption Test}

There is 3 classic assumption test that used at this research : normality test, heterocedasticity test and multicollinearity test.

Normality test is performed to see whether the disturbing or residual variable generated in the regression model is normally distributed or not. A good regression model is a model that has a normally distributed residual. In this study the normality test was measured by testing the non parametric statistical test of Kalmogorov - Smirnov (K - S).

The heterocedasticity test aims to test whether in the regression model there is a variance inequality of the residual one observation to the other. If the residual variant from one observation to another observes remains, then it is called homocedasticity and if different is called heteroscedasticity. A good regression model is homocedasticity or does not occur heterocedasticity. The heteroscedasticity test in this study used Glejser test.

Multicollinearity test aims to determine whether the regression model found a correlation between independent variables (independent). A good regression model should not be correlated between independent variables or multicollinearity.

\section{Hypothesis Test}

For hypothesis test this research used : multiregression analysis, significant test of coefficients ( $t$ test) and path test.

The author uses multiregression analysis because there are more than one independent variable. Significant test of coefficients ( $t$ test) used to show how far the influence of one independent variable individually in explaining the variation of the dependent variable. Decision making accept or reject the hypothesis in the study is based on consideration of the coefficient significance of each independent variable to the dependent variable.

Path test is intended to determine the comparison between direct and indirect effects of independent variables on dependent variables if through an intermediate variable (indirect influence) than if not through an intermediate variable (direct influence).

\section{Result \& Discussion}

\subsection{Validity \& Realiability Test Result}

From the validity test conducted through SPSS, with data from 110 respondents, the whole research instrument has $r$ value exceeding $r$ table value at $n=$ 110 , ie 0.1874 . So, can be concluded that the data on the main test of this study with 110 respondents valid and can be used as data on further analysis. The results of the validity test on the main test can be seen in Table 4.1. 


\begin{tabular}{|c|c|c|c|c|c|}
\hline & & Total & & & Total \\
\hline \multirow[t]{3}{*}{ VAR00001 } & Pearson Correlation & $.500^{\circ}$ & VAR00016 & Pearson Correlation & $.507^{7}$ \\
\hline & Sig. (2-tailed) &, 000 & & Sig. (2-tailed) & .000 \\
\hline & N & 110 & & N & 110 \\
\hline \multirow[t]{3}{*}{ VAR00002 } & Pearson Correlation & $.535^{\circ}$ & VAR00017 & Pearson Correlation & $547^{\circ}$ \\
\hline & Sig. (2-tailed) & .000 & & Sig. (2-talled) & .000 \\
\hline & N & 110 & & N & 110 \\
\hline \multirow[t]{3}{*}{ VAR00003 } & Pearson Correlation & $229^{\circ}$ & VAR00018 & Pearson Correlation & $.447^{\circ}$ \\
\hline & Sig. (2tailed) &, 022 & & Sig. (2taliled) & .000 \\
\hline & N & 110 & & $\mathrm{~N}$ & 110 \\
\hline \multirow[t]{3}{*}{ VAR00004 } & Pearson Correlation & $.447^{7}$ & VAR00019 & Pearson Correlation & $.586^{\circ}$ \\
\hline & Sig. (2täleded) & .000 & & Sig. (2-tailed) & 000 \\
\hline & $\mathrm{N}$ & 110 & & $\mathrm{~N}$ & 110 \\
\hline \multirow[t]{3}{*}{ VAR00005 } & Pearson Correlation & .621 & VAR00020 & Pearson Correlation & $.555^{\circ}$ \\
\hline & Sig. (2-tailed) & .000 & & Sig. (2-tailed) &, 000 \\
\hline & $\mathrm{N}$ & 110 & & N & 110 \\
\hline \multirow[t]{3}{*}{ VAR00006 } & Pearson Correlation & $.447^{-1}$ & VAR00021 & Pearson Correlation & $.610^{\circ}$ \\
\hline & Sig. (2-tailed) &, 000 & & Sig. (2-tailed) & .000 \\
\hline & N & 110 & & N & 110 \\
\hline \multirow[t]{3}{*}{ VAR00007 } & Pearson Correlation & .482 & VAR00022 & Pearson Correlation & .367 \\
\hline & Sig. (2tailed) &, 000 & & Sig. (2-tailed) & .000 \\
\hline & N & 110 & & $\mathrm{~N}$ & 110 \\
\hline \multirow[t]{3}{*}{ VAR00008 } & Pearson Correlation & $.487^{-}$ & VAR00023 & Pearson Correlation & $338^{\circ}$ \\
\hline & Sig. (2tailed) & .000 & & Sig. (2-tailed) & .001 \\
\hline & $\mathrm{N}$ & 110 & & N & 110 \\
\hline \multirow[t]{3}{*}{ VAR000009 } & Pearson Correlation & $500^{\circ}$ & VAR00024 & Pearson Correlation & $.405^{\circ}$ \\
\hline & Sig. (2-tailed) &, 000 & & Sig. (2-tailed) &, 000 \\
\hline & $\mathrm{N}$ & 110 & & $\mathrm{~N}$ & 110 \\
\hline \multirow[t]{3}{*}{ VAR00010 } & Pearson Correlation & $.491^{\circ}$ & VAR00025 & Pearson Correlation & $.313^{\circ}$ \\
\hline & Sig. (2-tailed) & .000 & & Sig. (2-tailed) &, 002 \\
\hline & $\mathrm{N}$ & 110 & & N & 110 \\
\hline \multirow[t]{3}{*}{ VAR00011 } & Pearson Correlation & $.439^{\circ}$ & VAR00026 & Pearson Correlation & $.647^{\circ}$ \\
\hline & Sig. (2-tailed) & .000 & & Sig. (2-tailed) & .000 \\
\hline & N & 110 & & N & 110 \\
\hline \multirow[t]{3}{*}{ VAR00012 } & Pearson Correation & $.600^{\circ}$ & VAR00027 & Pearson Correlation & $.665^{\circ}$ \\
\hline & Sig. (2-tailed) &, 000 & & Sig. (2-tailed) &, 000 \\
\hline & N & 110 & & $\mathrm{~N}$ & 110 \\
\hline \multirow[t]{3}{*}{ VAR00013 } & Pearson Correlation & $.514^{\circ}$ & VAR00028 & Pearson Correlation & $.534^{\circ}$ \\
\hline & Sig. (2-talled) & 000 & & Sig. (2-talled) &, 000 \\
\hline & $N$ & 110 & & $\mathrm{~N}$ & 110 \\
\hline \multirow[t]{3}{*}{ VAR00014 } & Pearson Correlation & $.576^{\circ}$ & VAR00029 & Pearson Correlation & $596^{\circ}$ \\
\hline & Sig. (2-talied) &, 000 & & Sig. (2-tailed) & .000 \\
\hline & N & 110 & & $\mathrm{~N}$ & 110 \\
\hline \multirow[t]{3}{*}{ VAR00015 } & Pearson Correlation & $.637^{-1}$ & Total & Pearson Correlation & 1 \\
\hline & Sig. (2-tailed) & .000 & & Sig. (2-tailed) & \\
\hline & N & 110 & & N & 110 \\
\hline
\end{tabular}

Table3.1Validity TestResult (respondent $n=110$ )

In the test of reliability using SPSS, for the number of respondents 110, obtained the value of Cornbach's Alpha is 0.738 and more than 0.1874 , so it can be concluded that the kusioner used is reliable or reliable to be continued as a research instrument. The results of the test reliability on the main test can be seen in Table 4.2.

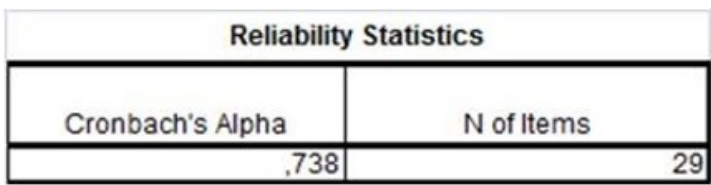

Table 3.2Reability Test Result $(\mathrm{n}=110)$

\subsection{Classic Assumption Test Result}

From the normality test results obtained significance value of 0.200 where the value is greater than 0.05 , it can be concluded that the research data is normally distributed.

From result of heterocedasticity test of significance variable of Quality $(\mathrm{K})$ equal to 0,488 , Price variable $(\mathrm{H})$ equal to 0,099 , Infrastructure variable (I) 0,573 and variable Perceived Value (PV) 0,932. The significance value of all variables is greater than 0.05 , so it can be concluded that the research data does not occur heterocedasticity.

From the result of multicolinearity test of tolerance value of Quality variable (K) 0,884 and VIF value 1,131 , Price variable $(\mathrm{H})$ tolerance value 0,803 and VIF value 1,246, Infrastructure variable (I) tolerance value 0,725 and VIF value 1,379 . As for the variable Perceived Value (PV) tolerance value of 0.924 and VIF value of 1.082. The tolerance value of all variables is greater than 0.10 and the VIF value is less than 10.0, so it can be concluded that the research data does not occur multicollinearity.

\subsection{Hypothesis Test Result}

From regression test result all significancy value is under 0,05 , it means that all hypothesis can be accepted that there is positive relationship between each variables.

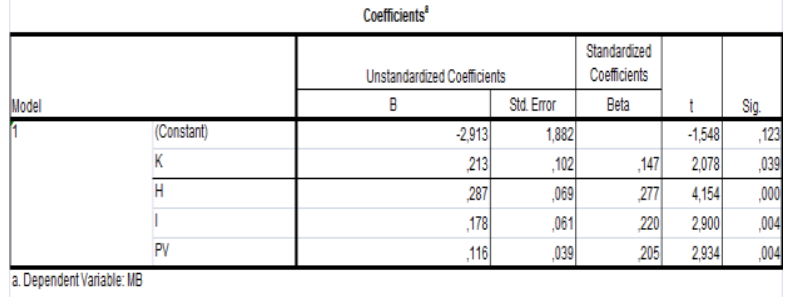

Table 3.3 Regression Test Result with Interest in Buying as Dependent Variable.

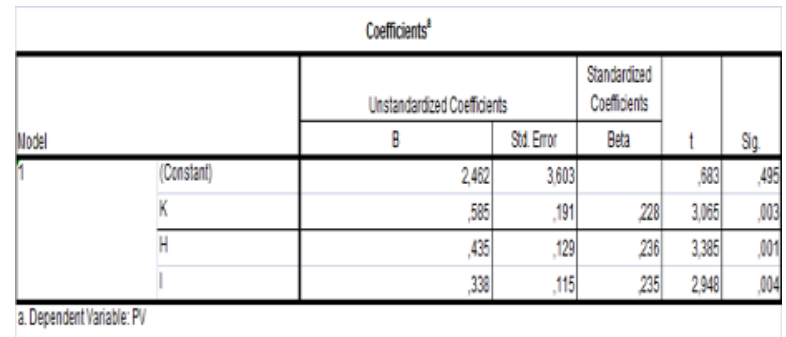

Table 3.4 Regression Test Result with Perceived Value as Dependent Variable.

Also form Table 3.3 and 3.4 , we can see that $\mathrm{T}$ value is over t tabel $(n=110)$ value : 1,65950 . So, it can be concluded that all hypothesis can be accepted.

For path analysis test, the direct effect of quality variables on buying interest is 0.147 . While the indirect effect of quality variable on buying interest if through perceived value is: $0,228 \times 0,205=0,04674$. So it can be concluded if the direct influence of quality variables 
on buying interest is more significant if compared indirect influence if through perceived variable value.

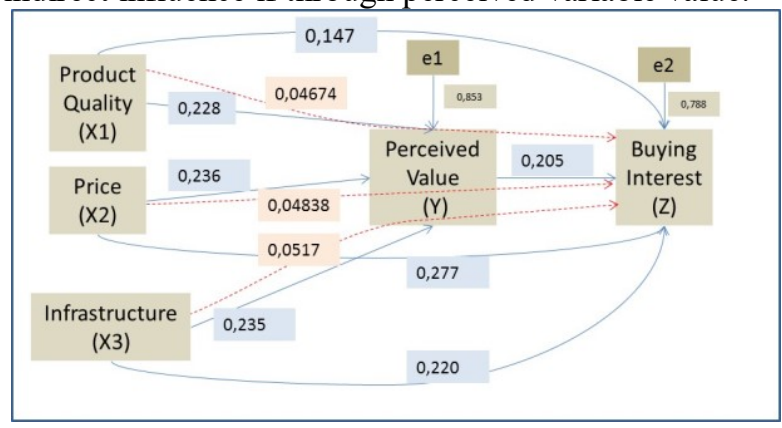

Fig 3.1. Path Analysis Test Result

The direct effect of price variables on buying interest by 0.277 . While the indirect effect of price variable on buying interest if through perceived value is: $0,236 \times 0,205=0,04838$. So it can be concluded if the direct influence of quality variables on buying interest is more significant if compared indirect influence if through perceived variable value.

The direct effect of quality variables on buying interest is 0.147 . While the indirect effect of quality variables on buying interest if through perceived value is: $0,235 \times 0,205=0,0517$. So it can be concluded if the direct influence of quality variables on buying interest is more significant if compared indirect influence if through perceived variable value.

\subsection{Discussion}

From hypothesis test we can conclude that all hypotesis can be accepted. For further analysis, this research also ask respondent for the deeper data of independent variables.

\section{Product Quality on Customer Perception}

- The distance of motorcycle for one battery charge

For the distance from the electric motorcycle, if asked further to the respondents about the acceptable mileage, $37.5 \%$ of respondents can accept the distance between $80-100 \mathrm{~km}$. For the distance of $50-80 \mathrm{~km}$ and also $>100 \mathrm{~km}$ respectively $30 \%$ of respondents who can accept it. And the remaining $2.5 \%$ of respondents can accept 20 - $50 \mathrm{~km}$. In general most respondents or $97.5 \%$ require mileage $>50 \mathrm{~km}$ for one battery charge.

\begin{tabular}{|c|c|c|}
\hline No & Mileage Expected & Percentage (\%) \\
\hline 1 & $20-50 \mathrm{~km}$ & 2,5 \\
\hline 2 & $50-80 \mathrm{~km}$ & 30 \\
\hline 3 & $80-100 \mathrm{~km}$ & 37,5 \\
\hline 4 & $>100 \mathrm{~km}$ & 30 \\
\hline
\end{tabular}

Table 3.5 Mileage of electric motorcycles expected by costumer
From the results of this survey the possibility of respondents still compare with the ability of a motorcycle with gasoline, which has a distance of up to $232 \mathrm{~km}$ for a one-time full tank of gasoline fuel.

However, when compared with the daily needs of motorcycle riders from respondents in the table 4:31, $40 \%$ of respondents traveled $5-20 \mathrm{~km}$ per day. Or if totaled $79 \%$ of respondents daily mileage less than 30 $\mathrm{km}$. Only $21 \%$ exceed $30 \mathrm{~km}$.

This means that there is a gap between the desire of the customer with the actual needs of customers. This matter need to be paid attention by automotive motorcycle industry producer so that can do education to society if want to market electric motorcycle.

\begin{tabular}{|c|c|c|}
\hline No & Daily Mileage Use & Percentage (\%) \\
\hline 1 & $<5 \mathrm{~km}$ & 19 \\
\hline 2 & $5-20 \mathrm{~km}$ & 40 \\
\hline 3 & $20-30 \mathrm{~km}$ & 20 \\
\hline 4 & $>30 \mathrm{~km}$ & 21 \\
\hline
\end{tabular}

Table 3.6 Daily mileage of motorcycle users

- Charge time of battery from empty to full condition

For charging time from empty to full, $40 \%$ of respondents can accept charging time between $3 \quad-7$ hours. If the total $85 \%$ of respondents can still accept charging time over 1 hour. And only $15 \%$ of respondents who want time charging under 1 hour.

\begin{tabular}{|c|c|c|}
\hline No & $\begin{array}{c}\text { Battery Charging Time } \\
\text { Expect }\end{array}$ & Percentage (\%) \\
\hline 1 & $7-9$ hours & 12 \\
\hline 2 & $3-7$ hours & 40 \\
\hline 3 & $1-3$ hours & 33 \\
\hline 4 & $<1$ hour & 15 \\
\hline
\end{tabular}

Table 3.7 Battery charging time that customers expect

Respondents can still accept and understand that electric motorcycles with batteries do take longer in charging. However, it is still necessary to socialize the users of motorcycles if you want to switch to electric motorcycle related recharging habits of energy. Because if it is only $7 \%$ of the respondents who fill the gasoline motorcycle every day. $93 \%$ of the rest fill gasoline motorcycle 2 days or more. 


\begin{tabular}{|c|c|c|}
\hline No & $\begin{array}{c}\text { Refueling Frequency } \\
\text { Habit }\end{array}$ & Percentage (\%) \\
\hline 1 & Everyday & 7 \\
\hline 2 & Every 2 days & 39 \\
\hline 3 & Every 3 days & 29 \\
\hline 4 & More than 3 days & 25 \\
\hline
\end{tabular}

Table 3.8 Habit of refueling frequency of motorcycle gasoline respondent

If you want to switch to electric motorcycle requires charging energy in this case fill the batteries every day.

\begin{tabular}{|c|c|c|}
\hline No & $\begin{array}{c}\text { Refueling Frequency } \\
\text { Habit }\end{array}$ & Percentage (\%) \\
\hline 1 & Full Tank & 50 \\
\hline 2 & Money Reference (Rupiah) & 40 \\
\hline 3 & Volume Reference (Litre) & 4 \\
\hline 4 & Random & 6 \\
\hline
\end{tabular}

Table 3.9 Habits method of refueling gasoline motorcycle respondents

For this energy charging habits $50 \%$ of respondents to fill up to full, so this habit will be in line with the habits to be formed on charging electric motorcycle batteries that will tend to fill up to full.

- Maximum speed of electric motorcycle

For maximum speed of electric motorcycle $44 \%$ of respondents can accept if the maximum speed of electric motorcycle ranges between $50-80 \mathrm{~km} /$ hour. If $91 \%$ of the respondents can accept if the speed of an electric motorcycle under $100 \mathrm{~km} /$ hour. Only 9\% of respondents wanted speeds above $100 \mathrm{~km} / \mathrm{h}$.

\begin{tabular}{|c|c|c|}
\hline No & Maximum Speed Expected & Percentage (\%) \\
\hline 1 & $30-50 \mathrm{~km} / \mathrm{h}$ & 12 \\
\hline 2 & $50-80 \mathrm{~km} / \mathrm{h}$ & 44 \\
\hline 3 & $80-100 \mathrm{~km} / \mathrm{h}$ & 35 \\
\hline 4 & $>100 \mathrm{~km} / \mathrm{h}$ & 9 \\
\hline
\end{tabular}

Table 3.10 Maximum speed of electric motorcycle expected

\begin{tabular}{|l|l|l|}
\hline No & Riding Habit Speed & Percentage (\%) \\
\hline
\end{tabular}

\begin{tabular}{|c|c|c|}
\hline 1 & $<50 \mathrm{~km} / \mathrm{h}$ & 11 \\
\hline 2 & $80-100 \mathrm{~km} / \mathrm{h}$ & 24 \\
\hline 3 & $50 \mathrm{~km} / \mathrm{h}$ & 54 \\
\hline 4 & $>100 \mathrm{~km} / \mathrm{h}$ & 11 \\
\hline
\end{tabular}

Table 3.11 The habits of motorcycle riding respondents

The above data is in line with the data of motorcycle driving habits of the respondents where $54 \%$ of respondents admitted the maximum speed that has traveled between $50-80 \mathrm{~km} /$ hour.

With this data the electric motorcycle manufacturer can set the target of electric motorcycle performance in this case its maximum speed at acceptable level by the customer.

\section{Price}

If it is experienced further by customer acceptable price on electric motorcycles, $53 \%$ of respondents want a price hike between $10-15$ million rupiahs, and $42 \%$ of respondents can accept price range 15-30 million rupiah. If $95 \%$ of respondents can accept a price range between 10 - 30 million rupiah for each unit of electric motorcycle.

\begin{tabular}{|c|c|c|}
\hline No & Acceptable Price (IDR) & Percentage (\%) \\
\hline 1 & $>50$ million & 2 \\
\hline 2 & $30-50$ million & 3 \\
\hline 3 & $15-30$ million & 42 \\
\hline 4 & $10-15$ million & 53 \\
\hline
\end{tabular}

Table 3.12. Acceptable Price to customer electric motorcycle

\begin{tabular}{|c|c|c|}
\hline No & Income per Month (IDR) & Percentage (\%) \\
\hline 1 & $<2.500 .000$ & 21 \\
\hline 2 & $5.000 .000-10.000 .000$ & 34 \\
\hline 3 & $2.500 .000-5.000 .000$ & 34 \\
\hline 4 & $>10.000 .000$ & 11 \\
\hline
\end{tabular}

Table 3.13. Income per month of respondents

If this data is linked to monthly income data from the respondents found a close relationship, of which $89 \%$ of respondents earn $<10$ million rupiah. With that income the ability to buy respondents in the price range 10 - 30 million rupiah.

3. Supporting Infratructure 
If experienced to respondents mengalam this infrastructure can be seen through the data charging method of electric motorcycle product. Seen from the results of deepening of respondents who want a feature of charging directly (charging) and replacement batteries (swap) on electric motorcycle, desired by more than $86 \%$ of respondents.

\begin{tabular}{|c|c|c|}
\hline No & Charging Method & $\begin{array}{c}\text { Percentage } \\
(\mathbf{\%})\end{array}$ \\
\hline 1 & $\begin{array}{c}\text { Charge (direct con- } \\
\text { nected) }\end{array}$ & 11 \\
\hline 2 & Swap Battery & 36 \\
\hline
\end{tabular}

Table 3.14. Electric motor batteries charging method desired by respondents

Availability of battery replacement location can disiasati automotive industry by exploiting the mushrooming mini market in Indonesia. So it can cover the lack of availability of charging infrastructure by replacing it into a reliable and available replacement battery replacement line across the region.

\section{Conclussion}

From the data and discussion we can conclude that :

1. Ha hypothesis is acceptable, there is a positive influence between quality with perceived value.

2. Hb hypothesis is acceptable, there is a positive influence between price and perceived value.

3. Hc hypothesis is acceptable, there is positive influence between infrastructure with perceived value.

4. Hd hypothesis is acceptable, there is positive influence between perceived value with buying interest.

5. He hypothesis is acceptable, there is a positive influence between quality with buying interest.

6. Hf hypothesis is acceptable, there is a positive influence between price and buying interest.

7. Hg hypothesis is acceptable, there is a positive influence between infrastructure and buying interest.

From the results of this study there are some suggestions from the author:

\section{Suggestions for further research}

Because of the limitations of this study only has 110 respondents, according to the authors in the next study should increase the number of respondents so that the accuracy of research is better.

Should also at the time of conducting research with an example of electric motorcycle products that can be tested by respondents in advance so that respondents better understand the statements that exist in the research questionnaire because it can be directly explained through existing products.

In addition it should be considered to conduct research on other variables that may affect both perceived value and on buying interest.

\section{Suggestions for industry}

From the results of this study can be seen that the quality, price and infrastructure have a good influence on perceived value and the interest in buying electric motorcycles. With the order of its biggest influence is price, then infrastructure and quality.

The price that can be accepted by respondents for electric motorcycle ranges between 10-30 million rupiah. For the desired infrastructure are battery charging facilities and also battery replacement (most respondents want both to exist).

While in terms of product quality, most respondents want the ability of their electric motorcycle: maximum speed $50-80 \mathrm{~km} /$ hour, mileage once charging $80-100 \mathrm{~km}$ battery and battery charging time is $3-7$ hours.

This is a challenge for the automotive industry in general in order to meet the expectations of consumers.

\section{Suggestions for the government}

Due to the most influential factor is the price and infrastructure, the authors suggest to the government to consider the existence of a subsidized policy for electric vehicles in order to meet consumer expectations. It also takes the role of government together with industry to provide battery charging infrastructure and battery exchange.

\section{References}

[1] KESDM (2015) Strategic Planning, Ministry of Energy and Mineral Resource 2015-2019, Jakarta.

[2] Hurst, Dave and Gartner, John. (2012). Pike Pulse Report: Electric Motorcycles and Scooters Assessment of Strategy and Execution for 12 Leading Electric Motorcycle and Scooter Manufacturers, Pike Research, Columbia USA. 
[3] Kinnear, Thomas C. and James R. Taylor. (1995). Marketing Research: An Applied Approach. McGraw Hill Text.

[4] Augusty, Ferdinand. (2006). Metode Penelitian Manajemen: Pedoman Penelitian untuk skripsi, Tesis dan Disertai Ilmu Manajemen. Semarang: Universitas Diponegoro.

[5] Kotler, Philip. (2008). Manajemen Pemasaran, Jilid 1 dan 2, Alih Bahasa Benyamin. Jakarta: PT.Indeks. Kelompok Gramedia.

[6] Sanchez, Javier. et al. (2006). Perceived Value of the Purchase of Tourism Product. Elsevier Tourism Management, 394-409

[7] Deloitte.(2011). Unplugged: Electric Vehicle Realities versus Consumer Expectations.

[8] Segal. R.(1995) Forecasting the Market for Electric Vehicles in California Using Conjoint Analysis, in The Energy Journal, vol, 16., no. 3, 89-111.

[9] Ping Liu, et al (2015) Long-range, Low-cost Electric Vehicles Enabled by Robust Energy Storage, MRS Energy \& Sustainability

[10] Greene, D. L. (2001). TAFV Alternative Fuels and Vehicles Choice Model Documentation, Centre for Transportation Analysis, Oak Ridge National Laboratory, and Report No. ORNL/TM-2001/134.

[11] Mau, P., Eyzaguirre, J., Jaccard, M. et al.(2008) the Neighbor Effect: Simulating Dynamics in Consumer Preferences for New Vehicle Technologies, in Ecological Economics.

[12] Dodi Triawan, Department of Management, Faculty of Economics, State University of Surabaya, "The Influence of Brand Image and Perception Value Against Motorcycle Buying Purpose Brand Honda Type PCX 150 (Study on Cafe Visitor at Tunjungan Plaza Surabaya), Journal of Management Sciences Volume 05 Number 01 - Department of Management Faculty of Economics, State University of Surabaya.

[13] Ning Wang and Yafei Liu, School of Automotive Studies, Tongji University, Shanghai, "Key factors influencing customers' willingness to purchase electric vehicles in China".

[14] Agus Sukasman Hidayat, "Analysis of Factors Influencing Interest in Buying New Yamaha Motorcycles in Semarang City", Master Program Management of Postgraduate Program of Diponegoro University of Semarang.

[15] Danu Kusmono, Master Program of Postgraduate Program Management of Widya Mandala Catholic University Surabaya, "The Influence of Marketing Mix Against Perceived Value and Purchasing Decision of ACR Brand Energy Saving Lamp Products in Surabaya"

[16] William Sierzchula, Sjoerd Bakker, et.al, Delft University of Technology, Faculty of Technology, Policy, and Management, The Netherlands, on his research paper, "The influence of financial incentives and other socio-economic Factors on electric vehicle adoption ". 